\title{
Correction to: The struggle against perceived negligence. A qualitative study of patients' experiences of adverse events in Norwegian hospitals
}

Gunn Hågensen*, Gudrun Nilsen, Grete Mehus and Nils Henriksen

Correction to: BMC Health Services Research (2018)

https://doi.org/10.1186/s12913-018-3101-2

In the original publication of this article [1], the corresponding email was changed to ghagensen@gmail.com.

Published online: 14 March 2019

\section{Reference}

1. Hågensen, et al. BMC Health Serv Res. 2018;18(302) https://doi.org/10.1186/ s12913-018-3101-2. 